\title{
Hypothesis: NDL proteins function in stress responses by regulating microtubule organization
}

\author{
Nisha Khatri and Yashwanti Mudgil* \\ Plant Molecular Biology Lab, Department of Botany, University of Delhi, New Delhi, India
}

N-MYC DOWNREGULATED-LIKE proteins (NDL), members of the alpha/beta hydrolase superfamily were recently rediscovered as interactors of G-protein signaling in Arabidopsis thaliana. Although the precise molecular function of NDL proteins is still elusive, in animals these proteins play protective role in hypoxia and expression is induced by hypoxia and nickel, indicating role in stress. Homology of NDL1 with animal counterpart N-MYC DOWNREGULATED GENE (NDRG) suggests similar functions in animals and plants. It is well established that stress responses leads to the microtubule depolymerization and reorganization which is crucial for stress tolerance. NDRG is a microtubule-associated protein which mediates the microtubule organization in animals

OPEN ACCESS

Edited by:

Girdhar Kumar Pandey, University of Delhi, India

Reviewed by:

Nabil l. Elsheery,

Tanta University, Egypt Hao Peng,

Washington State University, USA

*Correspondence: Yashwanti Mudgil

ymudgil@gmail.com;

ymudgil@botany.du.ac.in

Specialty section:

This article was submitted to Plant Physiology,

a section of the journal

Frontiers in Plant Science

Received: 15 August 2015 Accepted: 17 October 2015 Published: 31 October 2015

Citation:

Khatri N and Mudgil Y (2015) Hypothesis: NDL proteins function in stress responses by regulating

microtubule organization.

Front. Plant Sci. 6:947.

doi: 10.3389/fpls.2015.00947 by causing acetylation and increases the stability of $\alpha$-tubulin. As NDL1 is highly homologous to NDRG, involvement of NDL1 in the microtubule organization during plant stress can also be expected. Discovery of interaction of NDL with protein kinesin light chain- related 1 , enodomembrane family protein 70 , syntaxin-23, tubulin alpha-2 chain, as a part of $G$ protein interactome initiative encourages us to postulate microtubule stabilizing functions for NDL family in plants. Our search for NDL interactors in G protein interactome also predicts the role of NDL proteins in abiotic stress tolerance management. Based on published report in animals and predicted interacting partners for NDL in G protein interactome lead us to hypothesize involvement of NDL in the microtubule organization during abiotic stress management in plants.

Keywords: N-MYC DOWNREGULATED GENE, N-MYC DOWNREGULATED-LIKE, phospholipase D, phosphatidic acid, microtubule assembly, microtubule-associated protein, abiotic stress

\section{INTRODUCTION}

An average estimated yield loss by abiotic stress is more than 50\% across the world, caused mainly by salinity, drought and temperatures (Boyer, 1982). Matter of concern is that global population is likely to reach 10 billion by 2050 (almost doubled) (Tilman et al., 2002). So the generation of stress tolerant plants is the need of the hour (Smedema et al., 2000). Salinity is the most destructive and complex stress, affects more than 45 million hectares of irrigated land worldwide, in INDIA about 8.6 million hectare area is affected by salinity (Pathak, 2000).

Right from the beginning of seed germination till crop yield, salt stress affects plant adversely via ionic imbalance leading to toxicity, nutritional disorder, hampering metabolic processes, osmotic stress leading to membrane disorganization, reduction of cell divisionand expansion, and oxidative stress (Hasegawa et al., 2000; Duan et al., 2015; Khare et al., 2015). 
Although, the role of lipids in salt stress is not well understood, it has been indicated that expression of several phospholipase- $D$ (PLD) genes is induced by salt stress (Katagiri et al., 2001; Hong et al., 2010). Hydrolysis product of PLD, phosphatidic acid (PA) is shown to bind and activate mitogen-activated protein kinase 6 (MPK6), which in turn phosphorylates salt overly sensitive 1 (SOS1) transporter in vitro (Figure 1; Yu et al., 2010). The SOS1 gene encodes a plasma membrane $\mathrm{Na}+/ \mathrm{H}+$ antiporter, playing protective role in saline environment. These findings have indicated a link between lipid signaling, MAPK cascades, and salt stress tolerance in plants (Morris, 2010). Plant responses to salt stress include osmolyte biosynthesis, water flux control, and transport of ions for re-establishment of homeostasis and microtubule depolymerization and reorganization (Wang and Nick, 2001; Lü et al., 2007; Wang et al., 2007, 2010). Although all of the events are equally important for cell survival, microtubule depolymerization and reorganization are believed to be essential for plant survival under abiotic stress.

\section{NDRG AS A MICROTUBULE-ASSOCIATED PROTEIN (MAP)}

Microtubule organization is regulated by MAPs (Dixit and Cyr, 2004; Sedbrook, 2004). In animals, several MAPs have been identified and characterized. Detailed analysis of human N-MYC DOWNREGULATED GENE (NDRG) gene family showed that the family comprises of four members (NDRG1-4), each sharing
57-60\% amino acid sequence similarity (Qu et al., 2002). Among these, only NDRG1 has been reported to be a MAP which participates in the spindle checkpoint in animals (Kim et al., 2004).

Microtubule dynamics is affected by an array of reversible post-translational modifications including acetylation, phosphorylation, and palmitoylation (Piperno et al., 1987; Westermann and Weber, 2003; Zhang et al., 2003). Acetylated tubulin is one of the major characteristics of stabilized microtubule structure and may contribute to regulating microtubule dynamics (Westermann and Weber, 2003; Parrotta et al., 2014). Mammalian NDRG1 knockdown cell line have decreased accumulation of acetylated -tubulin and disrupted spindle fiber formation (Figure 1; Kim et al., 2004). Moreover, growing body of evidences also show that NDRG1 recruits on recycling endosomes in the Trans Golgi Network by binding to phosphatidylinositol 4-phosphate and interacts with membrane bound Rab4aGTPase (Kachhap et al., 2007). Kachhap et al. (2007) used a prostate cancer cell line to show that NDRG1 is a novel effector for the small GTPase, Rab4a, and is important in recycling E-cadherin in proliferating cells.

\section{STRUCTURAL SIMILARITIES BETWEEN NDRG1 AND NDL1}

In plants, NDL proteins were first reported in sunflower (SF21) as stigma and transmitting tissue cell specific proteins (Kräuter-Canham et al., 1997). Thereafter, studies on SF21

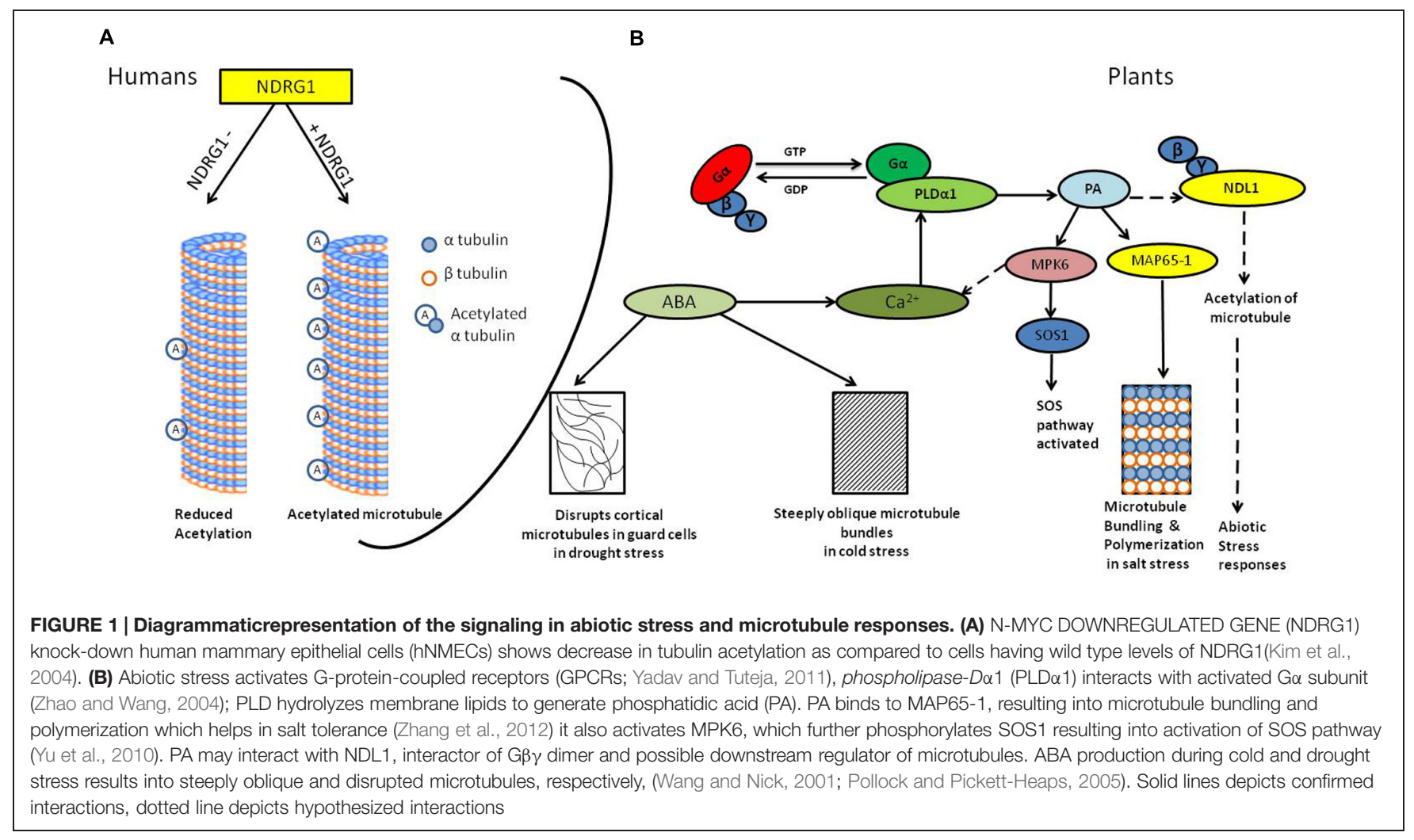


proteins identified it as a small gene family with putative role as a signaling molecules in pollen-pistil interaction. Across plant species, SF21 gene has been reported in dicots (Lycopersicon esculentum, Arabidopsis thaliana) monocots (Oryza sativa) (Lazarescu et al., 2006), gymnosperms as well as in the moss, physcomitrella patens (Lazarescu et al., 2010). Arabidopsis NDL gene family has three members NDL1, NDL2, and NDL3. All family members contain NDR domain, an alpha/beta hydrolase fold, a conserved hydrophobic patch of 23 amino acids and a conserved Asp. All these mentioned features strongly suggest that NDL proteins belong to NDR protein family. NDL proteins in A. thaliana are novel effectors of G-protein signaling playing important role in root and shoot development (Mudgil et al., 2009, 2013). G-protein core complex relay signal intracellularly with the help of downstream effectors or secondary messengers.

We previously observed that Mouse NDRG1 interacts with Arabidopsis AGB1/AGG1 and AGB1/AGG2, suggesting that this interaction is evolutionarily conserved (Mudgil et al., 2009). Human NDRG1 is $93 \%$ similar to mouse NDRG1 (Mudgil et al., 2009), so we can postulate similar interaction of human NDRG1 with plant's G protein components. Also, NDL in Arabidopsis and NDRG1 of mouse were shown to interact with the C-terminal domain of regulator of G-protein signaling (RGS1), a candidate seven-transmembrane receptor in AGB1/NDLmediated signaling via yeast two-hybrid (Mudgil et al., 2009).

N-MYC DOWNREGULATED GENE1 functions as a MAP and acetylates microtubules in human. NDRG1 also act as novel effector for the small GTPase. In plants, protein domains search revealed that all $\alpha$ tubulin family subunits contain GTPase domain as the tubulin C terminal domain so NDL might also interact with $\alpha$ tubulin in plants.

\section{MICROTUBULES DYNAMICS-ROLE IN ABIOTIC STRESS TOLERANCE}

Microtubules are the polymers of heterodimeric protein $\alpha \beta$-tubulin, which provides shape to cells and maintains tracks for vesicle transport and segregation of chromosome. Microtubule organization is regulated by microtubule-associated proteins (MAPs; Dixit and Cyr, 2004; Sedbrook, 2004). A variety of MAPs have been reported in higher plants. The MAP65 family and some of kinesin family are important in bundling and

TABLE 1 | N-MYC DOWNREGULATED GENE (NDRG1) and N-MYC DOWNREGULATED-LIKE (NDL1) shared interactors which are involved in common pathways/ processes.

\begin{tabular}{|c|c|c|c|}
\hline & NDRG1 a & NDL1 b & Reference \\
\hline Cyclin-dependent kinases & Cyclin-dependent kinase 15 & $\begin{array}{l}\text { Cyclin-dependent kinase - G1 } \\
\text { Cyclin-dependent kinase regulatory } \\
\text { subunit } 2\end{array}$ & $\begin{array}{l}\text { a (Huttlin et al., 2015) } \\
\text { b (Klopffleisch et al., 2011) }\end{array}$ \\
\hline $\begin{array}{l}\text { Calcium-dependent } \\
\text { phospholipid binding proteins }\end{array}$ & Annexin A5 & Annexin 1 & $\begin{array}{l}\text { a (Havugimana et al., 2012) } \\
\text { b (Klopffleisch et al., 2011) }\end{array}$ \\
\hline Heat shock protein & $\begin{array}{l}\text { HSPA4 } \\
\text { HSPA5 } \\
\text { HSP90AA1 }\end{array}$ & BOBBER 1 & $\begin{array}{l}\text { a (Tu et al., 2007; } \\
\text { Ambrosini et al., 2009) } \\
\text { b (Klopffleisch et al., 2011) }\end{array}$ \\
\hline $\begin{array}{l}\text { Eukaryotic translation initiation } \\
\text { factor }\end{array}$ & $\begin{array}{l}\text { Eukaryotic translation initiation factor } 2 \\
\text { Eukaryotic translation initiation factor } 3 \\
\text { Eukaryotic translation initiation factor } \\
4 \mathrm{H} \\
\text { DEAD (Asp-Glu-Ala-Asp) box helicase } 1 \\
\text { DEAD (Asp-Glu-Ala-Asp) box helicase } 5 \\
\text { DEAD (Asp-Glu-Ala-Asp) box } \\
\text { polypeptide 39B }\end{array}$ & $\begin{array}{l}\text { Eukaryotic initiation factor } 4 A \text {-III } \\
\text { DEAD-box ATP-dependent RNA } \\
\text { helicase } 2\end{array}$ & $\begin{array}{l}\text { a (Tu et al., 2007; } \\
\text { Kristensen et al., 2012) } \\
\text { b (Klopffleisch et al., 2011) }\end{array}$ \\
\hline Protein phosphatases & $\begin{array}{l}\text { Protein phosphatase } 2 \text {, regulatory } \\
\text { subunit B, alpha }\end{array}$ & protein phosphatase $2 \mathrm{~A}$ subunit $\mathrm{A} 2$ & $\begin{array}{l}\text { a (Tu et al., 2007) } \\
\text { b (Klopffleisch et al., 2011) }\end{array}$ \\
\hline $\begin{array}{l}\text { Components of cytoskeleton } \\
\text { machinery }\end{array}$ & $\begin{array}{l}\text { ACTG1, Actin, gamma } 1 \\
\text { kinesin family member } 5 B\end{array}$ & $\begin{array}{l}\text { TUA2, Tubulin alpha-2 chain } \\
\text { KINESIN LIGHT CHAIN-RELATED } 1\end{array}$ & $\begin{array}{l}\text { a (Tu et al., 2007) } \\
\text { b (Klopffleisch et al., 2011) }\end{array}$ \\
\hline Glutathione reductases & $\begin{array}{l}\text { Glutathione reductase } \\
\text { HEL-75 }\end{array}$ & HOT5, S-nitrosoglutathione reductase & $\begin{array}{l}\text { a (Kristensen et al., 2012) } \\
\text { b (Klopffleisch et al., 2011) }\end{array}$ \\
\hline Fatty acid pathway & $\begin{array}{l}\text { Fatty acid synthase (FASN) } \\
\text { Acyl-CoA synthetase long-chain family } \\
\text { member } 3 \text { (ACSL-3) } \\
\text { Acyl-CoA thioesterase } 7 \text { (ACOT7) }\end{array}$ & $\begin{array}{l}\text { KCS9 (3-KETOACYL-COA SYNTHASE } \\
\text { 9); acyltransferase/ catalytic/ } \\
\text { transferase, transferring acyl groups } \\
\text { other than amino-acyl groups } \\
\text { Lipoxygenase (LOX2) }\end{array}$ & $\begin{array}{l}\text { a (Tu et al., 2007; } \\
\text { Kristensen et al., 2012) } \\
\text { b (Klopffleisch et al., 2011) }\end{array}$ \\
\hline Salinity response & $\begin{array}{l}\text { ATPase, } \mathrm{Na}+/ \mathrm{K}+\text { transporting, alpha } 1 \\
\text { polypeptide }\end{array}$ & SLT1 (sodium- and lithium-tolerant 1) & $\begin{array}{l}\text { a (Tu et al., 2007) } \\
\text { b (Klopffleisch et al., 2011) }\end{array}$ \\
\hline
\end{tabular}


polymerization of the microtubules (Smertenko et al., 2004; Van Damme et al., 2004; Mao et al., 2005; Hamada, 2007) A. thaliana genome contains nine MAP65-related genes with different functions (Hussey et al., 2002).

Calcium is a well-known second messenger which participates in the stress signaling in plants (Knight, 2000; Xiong et al., 2002; Chinnusamy et al., 2005). Cortical microtubules have been suggested to regulate the calcium levels in the cells by regulating the activity of calcium channels (Thion et al., 1996; Himschoot et al., 2015). Treatment of microtubuledestabilizing drug improved the survival and growth of A. thaliana seedlings under salt stress while treatments with microtubule-stabilizing drug caused salt stress hypersensitivity (Wang et al., 2007). Moreover, reorientation of microtubules was also observed in maize roots and tobacco BY-2 cells upon short term exposure to salt stress (Blancaflor and Hasenstein, 1995; Dhonukshe et al., 2003). In A. thaliana, long term salt stress affected the cortical microtubule organization. spr1 mutant, [SPIRAL1(SPR1), a plant-specific MT-localizing protein] has right-handed helical root growth phenotype, salt stress suppresses this phenotype (Shoji et al., 2006). Directional cell expansion (anisotropic growth) is necessary for plant morphogenesis which is achieved by well-organized interphase, cortical microtubule and SPR1 is thought to control anisotropic cell expansion through MT arrangements (Nakajima et al., 2004, 2006). Mutation in critical amino acids of tubulin gene family (mainly located at longitudinal interface of the $\alpha$ and $\beta$ tubulins), in lateral contact region and in GTPase-activating region in $\alpha$ tubulin (Ishida et al., 2007) disrupts the proper organization and hence functions of microtubules (Hashimoto, 2013). Tubulin mutations affect cortical microtubule arrays in interphase resulting into altered directional growth. Mutation in TUA genes, $\alpha$ tubulin 6 and $\alpha$ tubulin 4 results into right handed helical array of cortical microtubules producing left handed helical growth phenotype, lefty 1 and lefty 2 , semi dominant skewing mutants (Thitamadee et al., 2002). These results indicated that the proper organization of microtubule is one of the critical factors for growth and development.

In addition, abscisic acid (ABA), which is produced in response to salt stress, also affects the organization of cortical microtubules (Sakiyama and Shibaoka, 1990; Shibaoka, 1994). In drought stress accumulation of $\mathrm{ABA}$ is one of the most pronounced ways to cope up with water deficit stress. ABA leads to stomata closure thereby decrease the water loss and also enhances water uptake by root (Boudsocq and Laurière, 2005). Dehydration triggers plasmolysis of cells and it consequently destroys microtubule (Pollock and PickettHeaps, 2005), ABA also disrupts cortical microtubules in guard cells, but not in epidermal cells (Jiang et al., 1996). During cold stress in wheat (Chinese winter wheat) ABA produced steeply oblique microtubule bundles (Figure 1; Wang and Nick, 2001).

Phospholipase D is involved in the rearrangement of cortical microtubules (Dhonukshe et al., 2003). In A. thaliana pld $\alpha 1$ salt-sensitive mutant cortical microtubule showed massive depolymerization patterns (Bargmann et al., 2009; Yu et al., 2010) compared to wild type control. However, upon salt removal from the growth medium organization was recovered in wild-type plants but not in pld $\alpha 1$ plants indicating involvement of PLD $\alpha 1$ in reorganizing microtubules after depolymerization induced by salt stress (Zhang et al., 2012).

Phosphatidic acid, the end product of $\mathrm{PLD} \alpha$ reaction, is a key regulator of microtubule polymerization; exogenous application of PA lead to recovery in salt-disrupted microtubule arrays in plda1 mutant (Zhang et al., 2012). PA regulates microtubule bundling and polymerization together with MAP65-1 and their interaction is important for salt tolerance. PA could not bind or bundle microtubules and rescue microtubule disruption caused by salt in the map65-1 mutant, suggesting that MAP651 is necessary for PA-mediated stabilization of microtubules (Zhang et al., 2012). There are two contradictory reports regarding interaction of tubulin and PA. In the first report, a mass spectrometry based approach was used to identify the PA binding proteins which showed that TUA2 is PA binding protein (Testerink et al., 2004). However, in the second report, it was found that neither PLD $\alpha 1$ nor PA species bound to either $\alpha$ - nor $\beta$ - tubulins. MAP65-1, a microtubule associated protein, was shown to bind to PA but not to other phospholipids like diacylglycerol, phosphatidylserine, phosphatidylinositol, phosphatidylethanolamine, or Phosphatidylcholines. These results indicate that $\mathrm{PA}$ requires other MAP to interact with microtubules (Zhang et al., 2012), further experimentation to confirm involvement/role of other MAPs is awaited.

Our analysis of existing information on NDL1 interactome shows interaction with Annexin 1 (ANNAT1) which has role in drought stress (Konopka-Postupolska et al., 2009), sodium and lithium-tolerant 1 (SLT1) which is involved in salt stress (Matsumoto et al., 2001) whereas lesion stimulating disease 1(LSD1) regulates cell death trigged by cold stress (Huang et al., 2010), O-Acetylserine (THIOL) Lyase (OAS-TL) Isoform A1 (OASA1) shows increased cadmium tolerance (Domínguez-Solís et al., 2001) and Arabidopsis Ribosomal Protein S27 (ARS27A) is involved in genotoxic stress (Revenkova et al., 1999). Also, comparative analysis shows overlap of NDRG1 and NDL1 interactors involved in similar pathways (Table 1).

Our proposed hypothesis that NDL might be playing role in stress mediated processes by regulating microtubule organization (Figure 1) can be easily tested by checking NDL1 effect on microtubules bundling and polymerization in vitro using purified NDL1 and tubulin proteins. Already available $n d l$ loss of function mutants can be used for checking and comparing status of acetylated tubulin in the absence and presence of NDL. Effects of various stress responses on tubulin pattern in relation to NDL levels can be further studied by analyzing GFP-tagged $\alpha$ tubulin (35S: GFP-TUA2) patterns in NDL up and downregulated backgrounds.

\section{ACKNOWLEDGMENT}

This work was supported by the UGC Major and DU-DST Purse grant to YM. 


\section{REFERENCES}

Ambrosini, G., Seelman, S. L., and Schwartz, G. K. (2009). Differentiation-related gene-1 decreases Bim stability by proteasome-mediated degradation. Cancer Res. 69, 6115-6121. doi: 10.1158/0008-5472.CAN-08-3024

Bargmann, B. O. R., Laxalt, A. M., Riet, B., Van Schooten, B., Merquiol, E., Testerink, C., et al. (2009). Multiple PLDs required for high salinity and water deficit tolerance in plants. Plant Cell Physiol. 50, 78-89. doi: $10.1093 / \mathrm{pcp} / \mathrm{pcn} 173$

Blancaflor, E. B., and Hasenstein, K. H. (1995). Time course and auxin sensitivity of cortical microtubule reorientation in maize roots. Protoplasma 185, 72-82. doi: 10.1007/BF01272755

Boudsocq, M., and Laurière, C. (2005). Osmotic signaling in plants. Multiple pathways mediated by emerging kinase families. Plant Physiol. 138, 1185-1194. doi: $10.1104 /$ pp.105.061275

Boyer, J. S. (1982). Plant productivity and environment. Science 218, 443-448. doi: 10.1126/science.218.4571.443

Chinnusamy, V., Jagendorf, A., and Zhu, J.-K. (2005). Understanding and improving salt tolerance in plants. Crop Sci. 45:437. doi: 10.2135/cropsci2005.0437

Dhonukshe, P., Laxalt, A. M., Goedhart, J., Gadella, T. W. J., and Munnik, T. (2003). Phospholipase d activation correlates with microtubule reorganization in living plant cells. Plant Cell 15, 2666-2679. doi: 10.1105/tpc.014977

Dixit, R., and Cyr, R. (2004). The cortical microtubule array: from dynamics to organization. Plant Cell 16, 2546-2552. doi: 10.1105/tpc.104.161030

Domínguez-Solís, J. R., Gutiérrez-Alcalá, G., Romero, L. C., and Gotor, C. (2001). The Cytosolic O-Acetylserine(thiol)lyase gene is regulated by heavy metals and can function in cadmium tolerance. J. Biol. Chem. 276, 9297-9302. doi: 10.1074/jbc.M009574200

Duan, L., Sebastian, J., and Dinneny, J. R. (2015). "Salt-stress regulation of root system growth and architecture in arabidopsis seedlings," in Plant Cell Expansion, ed J. M. Estevez (Berlin: Springer), 105-122.

Hamada, T. (2007). Microtubule-associated proteins in higher plants. J. Plant Res. 120, 79-98. doi: 10.1007/s10265-006-0057-9

Hasegawa, P. M., Bressan, R. A., Zhu, J.-K., and Bohnert, H. J. (2000). Plant cellular and molecular responses to high salinity. Annu. Rev. Plant Physiol. Plant Mol. Biol. 51, 463-499. doi: 10.1146/annurev.arplant.51.1.463

Hashimoto, T. (2013). Dissecting the cellular functions of plant microtubules using mutant tubulins. Cytoskeleton 70, 191-200. doi: 10.1002/cm.21099

Havugimana, P. C., Hart, G. T., Nepusz, T., Yang, H., Turinsky, A. L., Li, Z., et al. (2012). A census of human soluble protein complexes. Cell 150, 1068-1081. doi: 10.1016/j.cell.2012.08.011

Himschoot, E., Beeckman, T., Friml, J., and Vanneste, S. (2015). Calcium is an organizer of cell polarity in plants. Biochim. Biophys. Acta Mol. Cell Res. 1853, 2168-2172. doi: 10.1016/j.bbamcr.2015.02.017

Hong, Y., Zhang, W., and Wang, X. (2010). Phospholipase D and phosphatidic acid signalling in plant response to drought and salinity. Plant Cell Environ. 33, 627-635. doi: 10.1111/j.1365-3040.2009.02087.x

Huang, X., Li, Y., Zhang, X., Zuo, J., and Yang, S. (2010). The Arabidopsis LSD1 gene plays an important role in the regulation of low temperature-dependent cell death. New Phytol. 187, 301-312. doi: 10.1111/j.1469-8137.2010.03275.x

Hussey, P. J., Hawkins, T. J., Igarashi, H., Kaloriti, D., and Smertenko, A. (2002). The plant cytoskeleton: recent advances in the study of the plant microtubuleassociated proteins MAP-65, MAP-190 and the Xenopus MAP215-like protein, MOR1. Plant Mol. Biol. 50, 915-924. doi: 10.1023/A:1021236307508

Huttlin, E. L., Ting, L., Bruckner, R. J., Gebreab, F., Gygi, M. P., Szpyt, J., et al. (2015). The BioPlex network: a systematic exploration of the human interactome. Cell 162, 425-440. doi: 10.1016/j.cell.2015.06.043

Ishida, T., Kaneko, Y., Iwano, M., and Hashimoto, T. (2007). Helical microtubule arrays in a collection of twisting tubulin mutants of Arabidopsis thaliana. Proc. Natl. Acad. Sci. U.S.A. 104, 8544-8549. doi: 10.1073/pnas.07012 24104

Jiang, C. J., Nakajima, N., and Kondo, N. (1996). Disruption of microtubules by abscisic acid in guard cells of Vicia faba L. Plant Cell Physiol. 37, 697-701. doi: 10.1093/oxfordjournals.pcp.a029001

Kachhap, S. K., Faith, D., Qian, D. Z., Shabbeer, S., Galloway, N. L., Pili, R., et al. (2007). The N-Myc down regulated gene1 (NDRG1) is a Rab4a effector involved in vesicular recycling of E-cadherin. PLoS ONE 2:844. doi: 10.1371/journal.pone.0000844

Katagiri, T., Takahashi, S., and Shinozaki, K. (2001). Involvement of a novel Arabidopsis phospholipase D, AtPLD $\delta$, in dehydration-inducible accumulation of phosphatidic acid in stress signalling. Plant J. 26, 595-605. doi: 10.1046/j.1365-313X.2001.01060.x

Khare, T., Kumar, V., and Kishor, P. B. (2015). Na+ and Cl- ions show additive effects under $\mathrm{NaCl}$ stress on induction of oxidative stress and the responsive antioxidative defense in rice. Protoplasma 252, 1149-1165. doi: 10.1007/s00709014-0749-2

Kim, K. T., Ongusaha, P. P., Hong, Y. K., Kurdisiani, S. K., Nakamura, M., Lu, K. P., et al. (2004). Function of Drg1/Rit42 in p53-dependent mitotic spindle checkpoint. J. Biol. Chem. 279, 38597-38602. doi: 10.1074/jbc.M40078 1200

Klopffleisch, K., Phan, N., Augustin, K., Bayne, R. S., Booker, K. S., Botella, J. R., et al. (2011). Arabidopsis G-protein interactome reveals connections to cell wall carbohydrates and morphogenesis. Mol. Syst. Biol. 7:532. doi: $10.1038 / \mathrm{msb} .2011 .66$

Knight, H. (2000). Calcium signaling during abiotic stress in plants. Int. Rev. Cytol. 195, 269-324. doi: 10.1016/S0074-7696(08) 62707-2

Konopka-Postupolska, D., Clark, G., Goch, G., Debski, J., Floras, K., Cantero, A., et al. (2009). The role of annexin 1 in drought stress in Arabidopsis. Plant Physiol. 150, 1394-1410. doi: 10.1104/pp.109.135228

Kräuter-Canham, R., Bronner, R., Evrard, J. L., Hahne, G., Friedt, W., and Steinmetz, A. (1997). A transmitting tissue- and pollen-expressed protein from sunflower with sequence similarity to the human RTP protein. Plant Sci. 129, 191-202. doi: 10.1016/S0168-9452(97)00182-9

Kristensen, A. R., Gsponer, J., and Foster, L. J. (2012). A high-throughput approach for measuring temporal changes in the interactome. Nat. Methods 9, 907-909. doi: $10.1038 /$ nmeth. 2131

Lazarescu, E., Friedt, W., Horn, R., and Steinmetz, A. (2006). Expression analysis of the sunflower SF21 gene family reveals multiple alternative and organ-specific splicing of transcripts. Gene 374, 77-86. doi: 10.1016/j.gene.2006.01.025

Lazarescu, E., Friedt, W., and Steinmetz, A. (2010). Organ-specific alternatively spliced transcript isoforms of the sunflower SF21C gene. Plant Cell Rep. 29, 673-683. doi: 10.1007/s00299-010-0853-5

Lü, B., Gong, Z., Wang, J., Zhang, J., and Liang, J. (2007). Microtubule dynamics in relation to osmotic stress-induced ABA accumulation in Zea mays roots. J. Exp. Bot. 58, 2565-2572. doi: 10.1093/jxb/erm 107

Mao, T., Jin, L., Li, H., Liu, B., and Yuan, M. (2005). Two microtubule-associated proteins of the Arabidopsis MAP65 family function differently on microtubules. Plant Physiol. 138, 654-662. doi: 10.1104/pp.104.052456

Matsumoto, T. K., Pardo, J. M., Takeda, S., Bressan, R. A., and Hasegawa, P. M. (2001). Tobacco and Arabidiopsis SLT1 mediate salt tolerance of yeast. Plant Mol. Biol. 45, 489-500. doi: 10.1023/A:1010659207604

Morris, P. C. (2010). Integrating lipid signalling, mitogen-activated protein kinase cascades and salt tolerance. New Phytol. 188, 640-643. doi: 10.1111/j.14698137.2010.03507.x

Mudgil, Y., Uhrig, J. F., Zhou, J., Temple, B., Jiang, K., and Jones, A. M. (2009). Arabidopsis N-MYC DOWNREGULATED-LIKE1, a positive regulator of auxin transport in a G protein-mediated pathway. Plant Cell 21, 3591-3609. doi: $10.1105 /$ tpc.109.065557

Mudgil, Y., Ghawana, S., and Jones, A. M. (2013). N-MYC down-regulated-like proteins regulate meristem initiation by modulating auxin transport and MAX2 expression. PLoS ONE 8:e77863. doi: 10.1371/journal.pone.0077863

Nakajima, K., Furutani, I., Tachimoto, H., Matsubara, H., and Hashimoto, T. (2004). SPIRAL1 encodes a plant-specific microtubule-localized protein required for directional control of rapidly expanding Arabidopsis cells. Plant Cell 16, 1178-1190. doi: 10.1105/tpc.017830

Nakajima, K., Kawamura, T., and Hashimoto, T. (2006). Role of the SPIRAL1 gene family in anisotropic growth of Arabidopsis thaliana. Plant Cell Physiol. 47, 513-522. doi: 10.1093/pcp/pcj020

Parrotta, L., Cresti, M., and Cai, G. (2014). Accumulation and post-translational modifications of plant tubulins. Plant Biol. 16, 521-527. doi: 10.1111/plb.12104

Pathak, P. S. (2000). Agro forestry: a tool for arresting land degradation. Indian Farm. 49, 15-19. 
Piperno, G., LeDizet, M., and Chang, X. J. (1987). Microtubules containing acetylated alpha-tubulin in mammalian cells in culture. J. Cell Biol. 104, 289302. doi: $10.1083 /$ jcb.104.2.289

Pollock, F. M., and Pickett-Heaps, J. D. (2005). Spatial determinants in morphogenesis: recovery from plasmolysis in the diatom Ditylum. Cell Motil. Cytoskeleton 60, 71-82. doi: 10.1002/cm.20044

Qu, X., Zhai, Y., Wei, H., Zhang, C., Xing, G., Yu, Y., et al. (2002). Characterization and expression of three novel differentiation-related genes belong to the human NDRG gene family. Mol. Cell. Biochem. 229, 35-44. doi: 10.1023/A:1017934810825

Revenkova, E., Masson, J., Koncz, C., Afsar, K., Jakovleva, L., and Paszkowski, J. (1999). Involvement of Arabidopsis thaliana ribosomal protein S27 in mRNA degradation triggered by genotoxic stress. EMBO J. 18, 490-499. doi: 10.1093/emboj/18.2.490

Sakiyama, M., and Shibaoka, H. (1990). Effects of abscisic acid on the orientation and cold stability of cortical microtubules in epicotyl cells of the dwarf pea. Protoplasma 157, 165-171. doi: 10.1007/BF01322649

Sedbrook, J. C. (2004). MAPs in plant cells: delineating microtubule growth dynamics and organization. Curr. Opin. Plant Biol. 7, 632-640. doi: 10.1016/j.pbi.2004.09.017

Shibaoka, H. (1994). Plant hormone-induced changes in the orientation of cortical microtubules: alterations in the cross-linking between microtubules and the plasma membrane. Annu. Rev. Plant Biol. 45, 527-544. doi: 10.1146/annurev.pp.45.060194.002523

Shoji, T., Suzuki, K., Abe, T., Kaneko, Y., Shi, H., Zhu, J. K., et al. (2006). Salt stress affects cortical microtubule organization and helical growth in Arabidopsis. Plant Cell Physiol. 47, 1158-1168. doi: 10.1093/pcp/pcj090

Smedema, L. K., Abdel-Dayem, S., and Ochs, W. J. (2000). Drainage and agricultural development. Irrig. Drain. Syst. 14, 223-235. doi: 10.1023/A:1026570823692

Smertenko, A. P., Chang, H.-Y., Wagner, V., Kaloriti, D., Fenyk, S., Sonobe, S., et al. (2004). The Arabidopsis microtubule-associated protein AtMAP65-1: molecular analysis of its microtubule bundling activity. Plant Cell 16, 2035-2047. doi: 10.1105/tpc.104.023937

Testerink, C., Dekker, H. L., Lim, Z. Y., Johns, M. K., Holmes, A. B., De Koster, C. G., et al. (2004). Isolation and identification of phosphatidic acid targets from plants. Plant J. 39, 527-536. doi: 10.1111/j.1365-313X.2004.02152.x

Thion, L., Mazars, C., Thuleau, P., Graziana, A., Rossignol, M., Moreau, M., et al. (1996). Activation of plasma membrane voltage-dependent calcium-permeable channels by disruption of microtubules in carrot cells. FEBS Lett. 393, 13-18. doi: 10.1016/0014-5793(96)00844-7

Thitamadee, S., Tuchihara, K., and Hashimoto, T. (2002). Microtubule basis for left-handed helical growth in Arabidopsis. Nature 417, 193-196. doi: $10.1038 / 417193 a$

Tilman, D., Cassman, K. G., Matson, P. A., Naylor, R., and Polasky, S. (2002). Agricultural sustainability and intensive production practices. Nature 418, 671-677. doi: 10.1038/nature01014

Tu, L. C., Yan, X., Hood, L., and Lin, B. (2007). Proteomics analysis of the interactome of $\mathrm{N}$-myc downstream regulated gene 1 and its interactions with the androgen response program in prostate cancer cells. Mol. Cell. Proteomics 6, 575-588. doi: 10.1074/mcp.M600249-MCP200
Van Damme, D., Van Poucke, K., Boutant, E., Ritzenthaler, C., Inzé, D., and Geelen, D. (2004). In vivo dynamics and differential microtubulebinding activities of MAP65 proteins. Plant Physiol. 136, 3956-3967. doi: 10.1104/pp.104.051623

Wang, C., Li, J., and Yuan, M. (2007). Salt tolerance requires cortical microtubule reorganization in Arabidopsis. Plant Cell Physiol. 48, 1534-1547. doi: $10.1093 / \mathrm{pcp} / \mathrm{pcm} 123$

Wang, C., Zhang, L., Yuan, M., Ge, Y., Liu, Y., Fan, J., et al. (2010). The microfilament cytoskeleton plays a vital role in salt and osmotic stress tolerance in Arabidopsis. Plant Biol. 12, 70-78. doi: 10.1111/j.1438-8677.2009. 00201.x

Wang, Q. Y., and Nick, P. (2001). Cold acclimation can induce microtubular cold stability in a manner distinct from abscisic acid. Plant Cell Physiol. 42, 999-1005. doi: 10.1093/pcp/pce135

Westermann, S., and Weber, K. (2003). Post-translational modifications regulate microtubule function. Nat. Rev. Mol. Cell Biol. 4, 938-947. doi: $10.1038 / \mathrm{nrm} 1260$

Xiong, L., Schumaker, K. S., and Zhu, J. (2002). Cell signaling during cold, drought, and salt stress. Plant Cell 14(Suppl.), S165-S184. doi: 10.1105/tpc.000596.S166

Yadav, D. K., and Tuteja, N. (2011). Rice G-protein coupled receptor (GPCR): in silico analysis and transcription regulation under abiotic stress. Plant Signal. Behav. 6, 1079-1086. doi: 10.4161/psb.6.8.15771

Yu, L., Nie, J., Cao, C., Jin, Y., Yan, M., Wang, F., et al. (2010). Phosphatidic acid mediates salt stress response by regulation of MPK6 in Arabidopsis thaliana. New Phytol. 188, 762-773. doi: 10.1111/j.1469-8137.2010.03 422.x

Zhang, Q., Lin, F., Mao, T., Nie, J., Yan, M., Yuan, M., et al. (2012). Phosphatidic acid regulates microtubule organization by interacting with MAP65-1 in response to salt stress in Arabidopsis. Plant Cell 24, 4555-4576. doi: 10.1105/tpc.112.104182

Zhang, Y., Li, N., Caron, C., Matthias, G., Hess, D., Khochbin, S., et al. (2003). HDAC-6 interacts with and deacetylates tubulin and microtubules in vivo. EMBO J. 22, 1168-1179. doi: 10.1093/emboj/cdg115

Zhao, J., and Wang, X. (2004). Arabidopsis phospholipase D $\alpha 1$ interacts with the heterotrimeric G-protein $\alpha$-subunit through a motif analogous to the DRY motif in G-protein-coupled receptors. J. Biol. Chem. 279, 1794-1800. doi: 10.1074/jbc.M309529200

Conflict of Interest Statement: The Guest Associate Editor Girdhar Kumar Pandey declares that, despite being affiliated with the same institute as the authors Nisha Khatri and Yashwanti Mudgil, the review process was handled objectively. The authors declare that the research was conducted in the absence of any commercial or financial relationships that could be construed as a potential conflict of interest.

Copyright (c) 2015 Khatri and Mudgil. This is an open-access article distributed under the terms of the Creative Commons Attribution License (CC BY). The use, distribution or reproduction in other forums is permitted, provided the original author(s) or licensor are credited and that the original publication in this journal is cited, in accordance with accepted academic practice. No use, distribution or reproduction is permitted which does not comply with these terms. 